\title{
DIFFERENCES IN MOTOR SKILLS IN GIRLS ENGAGED IN RHYTHMIC GYMNASTICS AND MODERN DANCE
}

\section{RÓŻNICE W UMIEJĘTNOŚCIACH MOTORYCZNYCH U DZIEWCZĄT TRENUJĄCYCH GIMNASTYKĘ RYTMICZNĄ I TANIEC NOWOCZESNY}

\author{
Boris Popović $^{1(A, C, D, E, F, G)}$, Nataša Penčići ${ }^{1(A, B, C, D, F)}$, Aleksandra Spasićc ${ }^{1(B, F)}$
}

${ }^{1}$ Faculty of Sport and Physical Education, University of Novi Sad, Serbia

Authors' contribution Wkład autorów: A. Study design/planning zaplanowanie badań B. Data collection/entry zebranie danych C. Data analysis/statistics dane - analiza i statystyki D. Data interpretation interpretacja danych E. Preparation of manuscript przygotowanie artykułu F. Literature analysis/search wyszukiwanie i analiza literatury G. Funds collection zebranie funduszy
Tables: 2

Figures: 0

References: 28

Submitted: 2017 Sep 23

Accepted: 2017 Oct 04

\section{Summary}

Background. The following study attempts to compare the motor skills of younger schoolaged female children (7-9 and 9-11) who attended rhythmic gymnastics classes and those who participated in modern dance classes.

Material and methods. The study involved 30 girls aged 7-9 and 35 aged 9-11 who attended rhythmic gymnastics, as well as 36 female children aged 7-9 and 40 aged 9-11 doing modern dance. Sixteen tests of motor skills were conducted to assess the coordination of the whole body, lower-limb explosive strength, lower-limb flexibility, repetitive bodily movement and its frequency. The multivariate analysis of variance (MANOVA) was applied for determining quantitive differences between the two groups of girls.

Results. The results of the research showed a significant difference in most motor variables at the level of statistical significance of $\mathrm{P}=0.05$ between the two categories of examinees, especially in the older age group (9-11), showcasing better results in the girls engaged in rhythmic gymnastics.

Conclusions. The findings may help to understand the specific requirements concerning girls' competing in rhythmic gymnastics, as well as their everyday training process, which is considerably more demanding than that of modern dance performers, which may however ultimately result in higher-quality motor skills, especially of coordination, static balance and flexibility.

Keywords: motor skills, physical fitness, rhythmic gymnastics, modern dance, young girls

\section{Streszczenie}

Wprowadzenie. Poniższe badanie porównuje umiejętności motorycznych młodszych dziewcząt w wieku szkolnym (7-9 i 9-11 lat), które uczęszczały na zajęcia z gimnastyki artystycznej i tańca nowoczesnego.

Materiał i metody. W badaniu wzięło udział 30 dziewcząt w wieku 7-9 lat i 35 w wieku 9-11 lat, które uczyły się gimnastyki artystycznej oraz 36 dziewcząt w wieku 7-9 lat i $40 \mathrm{w}$ wieku 9-11 lat, które zajmowały sie tańcem współczesnym. Przeprowadzono szesnaście testów umiejętności motorycznych, aby ocenić koordynację całego ciała, siłę wybuchową dolnych kończyn oraz ich elastyczność, powtarzalne ruchy ciała i ich częstotliwość. Zastosowano wielowymiarową analizę wariancji (MANOVA) do określenia różnic ilościowych między dwiema grupami dziewcząt.

Wyniki. Wyniki badań wskazały na istotną różnicę w większości zmiennych motorycznych na poziomie istotności statystycznej $\mathrm{P}=0,05$ pomiędzy dwiema kategoriami badanych, szczególnie w starszej grupie wiekowej (9-11), wykazujących lepsze wyniki u dziewcząt zajmujących się gimnastyką rytmiczną.

Wnioski. Wyniki badań mogą pomóc w zrozumieniu specyficznych wymagań dotyczących rywalizacji dziewcząt w gimnastyce rytmicznej, a także ich codziennego treningu, który jest znacznie bardziej wymagający niż w przypadku ćwiczacych taniec współczesny, co z kolei może ostatecznie skutkować lepszymi umiejętnościami motorycznymi, zwłaszcza koordynacji, równowagi statycznej i elastyczności.

Słowa kluczowe: zdolności motoryczne, sprawność fizyczna, gimnastyka rytmiczna, taniec nowoczesny, młode dziewczęta 


\section{Introduction}

Numerous studies have focused on morphological and physiological characteristics of successful performance $[1,2]$ and talent detection [3,4] in various sports. Blanksby et al. [5] underlined that the success of any talent identification and development programme depends on a clear understanding of the specific performance requirements in the particular sport. Information on these requirements, based on a variety of morphological, physiological, and physical fitness measurements, is useful in any sport, including modern dance as well as rhythmic gymnastics, a highly specialized discipline that involves the use of 5 hand apparatuses (hoop, rope, ball, clubs, and ribbon) [6].

For instance, it has been shown that dance classes in the cross-country skiers training process in the youth aged 12-15, both genders, have a positive effect on the development of speed and agility, as well as on the mobility of joints, muscles, and lateral bending of the spine [7]. Thus, introducing dance to the curricula at the young age leads to better development of children's motor abilities.

The physical demands imposed on rhythmic gymnasts and modern dancers by choreographers and performance schedules make their physical fitness just as important to them as skill development [8]. Rhythmic gymnastics represents a mixture of gymnastics, ballet and movements to the sounds of music while using suitable props. As for the girls practising this sport, it helps them to entice and develops motor and coordination skills, grace, creativity and musicality. Moreover, it enables them to build their natural flexibility and strengthen the muscles of the entire body. Because it affects proper muscular development and posture in a very favourable manner, it concurrently represents an excellent basis for the further practice of any other sport. Elite rhythmic gymnasts should have an appropriate physique, maintain low body fat, and acquire specific physical abilities (i.e. flexibility, explosive strength, coordination, balance) to achieve satisfactory performance $[9,10]$.

Furthermore, successful performance in rhythmic gymnastics requires years of practice and training that starts at the early age of 6 years and continues until adolescence [6]. Therefore, athletes reach a high competitive level and train intensively, stressing their cardiovascular and musculoskeletal systems during the developmental period [11]. On the other hand, during this time, growth involves changes in the body size, as well as in different physiological characteristics, motor skills and abilities.

Owing to its rhythm design, esthetic values, and movement of the entire body to music at a certain tempo, modern dance contributes to the development of many motor skills and abilities. Since modern dance is also a competitive sport in which a dancer strives to reach perfection in performance and, consequently, achieve superb results, there is a need for a planned and defined elaboration of the training process and its implementation [12]. As in most sports, dance fitness depends on the individuals' ability to work under aerobic [13,14] and anaerobic [15] conditions, as well as on their capacity to develop high levels of muscle tension, i.e. muscle strength [16,17]. Joint mobility/muscle flexibility [18] and body composition [19,20] are also vital aspects of dance fitness. However, no single fitness measurement can predict success in the discipline, as they vary markedly depending on numerous parameters including age, sex and level of performance [21].

The purpose of this study is to compare the motor skills of younger school-aged girls (7-9 and 9-11) who attend rhythmic gymnastics classes and those shown by the girls doing courses of modern dance.

\section{Material and methods}

The subsample of examinees practising rhythmic gymnastics comprised 30 girls aged 7-9, as well as 35 girls aged 9-11, whereas the subsample of examinees doing modern dancing consisted of 36 girls aged 7-9 and 40 girls aged 9-11, as defined according to the decimal value of years.

Measuring motor skills in girls, i.e. motor skills testing, was conducted following the standardisation of motor skills tests [22]. A selection of tests was made according to the performed structural and motor analysis of common activities in rhythmic gymnastics and modern dance, which in the authors' view, represent motor skills predominantly contributing to achievements in the respective sports. 15 motor skills tests were selected to assess coordination, agility, lower-limb explosive strength, flexibility and balance.

All the collected data were analysed using a descriptive statistical procedure. Regarding each motor variable, arithmetic mean (AM), standard deviation (SD), minimum (MIN) and maximum (MAX) result values were calculated. To determine quantitative differences between the systems of motor variables of the two groups of examinees, particularly concerning both age groups, the multivariate analysis of variance (MANOVA) was applied, whereas for determining differences among each motor variable, the univariate analysis of variance (ANOVA) was applied. A smaller level of statistical inference being $p=0.05$ was defined as the criterion of statistical significance. 


\section{Results and discussion}

Table 1. shows the analysis of differences in motor variables between the group of girls practising rhythmic gymnastics and the one doing modern dance, aged 7-9. The results of multivariate analysis of variance showed statistically significant differences of the entire system of motor variables between the two examined groups existing only at the level of statistical significance of $\mathrm{P}=0.04$.

Table 1. Analysis of differences of motor variables between the two groups of girls aged 7-9

\begin{tabular}{|c|c|c|c|c|c|}
\hline VARIABLES & $\mathbf{G r}$ & AM & SD & $\mathbf{f}$ & $\mathbf{p}$ \\
\hline Obstacle course backwards (s) & $\begin{array}{l}\mathbf{1} \\
2\end{array}$ & $\begin{array}{l}\mathbf{1 8 . 6 8} \\
23.93\end{array}$ & $\begin{array}{l}4.55 \\
8.43\end{array}$ & 4.59 & 0.04 \\
\hline Threading and skipping (s) & $\begin{array}{l}1 \\
2\end{array}$ & $\begin{array}{l}18.07 \\
\mathbf{1 6 . 4 0}\end{array}$ & $\begin{array}{c}2.54 \\
3.7\end{array}$ & 2.03 & 0.16 \\
\hline Standing broad jump $(\mathrm{cm})$ & $\begin{array}{l}1 \\
2\end{array}$ & $\begin{array}{l}122.88 \\
\mathbf{1 4 8 . 6 9}\end{array}$ & $\begin{array}{l}24.03 \\
15.28\end{array}$ & 11.27 & 0.00 \\
\hline Triple jump (cm) & $\begin{array}{l}1 \\
2\end{array}$ & $\begin{array}{l}289.22 \\
\mathbf{3 8 0 . 1 9}\end{array}$ & $\begin{array}{c}114.76 \\
15.41\end{array}$ & 73.97 & 0.00 \\
\hline Left leg front raise $\left(^{\circ}\right)$ & $\begin{array}{l}\mathbf{1} \\
2\end{array}$ & $\begin{array}{l}\mathbf{1 2 8 . 6 2} \\
106.54\end{array}$ & $\begin{array}{l}17.17 \\
13.75\end{array}$ & 14.12 & 0.00 \\
\hline Right leg front raise $\left(^{\circ}\right)$ & $\begin{array}{l}\mathbf{1} \\
2\end{array}$ & $\begin{array}{l}\mathbf{1 3 4 . 6 3} \\
110.77\end{array}$ & $\begin{array}{l}18.80 \\
15.39\end{array}$ & 13.54 & 0.00 \\
\hline Left leg lateral lift $\left(^{\circ}\right)$ & $\begin{array}{l}\mathbf{1} \\
2 \\
\end{array}$ & $\begin{array}{c}\mathbf{1 2 7 . 0 6} \\
86.92\end{array}$ & $\begin{array}{l}18.13 \\
10.90\end{array}$ & 48.54 & 0.00 \\
\hline Right leg lateral lift $\left({ }^{\circ}\right)$ & $\begin{array}{l}1 \\
2\end{array}$ & $\begin{array}{c}\mathbf{1 2 5 . 6 3} \\
81.92\end{array}$ & $\begin{array}{l}17.20 \\
12.34\end{array}$ & 59.02 & 0.00 \\
\hline Left leg rear raise $\left(^{\circ}\right)$ & $\begin{array}{l}1 \\
2\end{array}$ & $\begin{array}{l}81.63 \\
46.46\end{array}$ & $\begin{array}{l}22.56 \\
19.83\end{array}$ & 27.24 & 0.00 \\
\hline Right leg rear raise $\left(^{\circ}\right)$ & $\begin{array}{l}1 \\
2\end{array}$ & $\begin{array}{l}\mathbf{8 6 . 9 4} \\
49.38\end{array}$ & $\begin{array}{l}22.60 \\
12.92\end{array}$ & 28.26 & 0.00 \\
\hline $\begin{array}{l}\text { Deep forward bend while } \\
\text { seated straddled }(\mathrm{cm})\end{array}$ & $\begin{array}{l}\mathbf{1} \\
2\end{array}$ & $\begin{array}{l}\mathbf{5 3 . 9 7} \\
52.29\end{array}$ & $\begin{array}{l}6.04 \\
7.48\end{array}$ & 0.45 & 0.51 \\
\hline Side stepping (freq) & $\begin{array}{l}1 \\
2\end{array}$ & $\begin{array}{l}11.13 \\
\mathbf{1 4 . 3 1}\end{array}$ & $\begin{array}{l}2.22 \\
2.25\end{array}$ & 14.58 & 0.00 \\
\hline T-test (s) & $\begin{array}{l}1 \\
2\end{array}$ & $\begin{array}{l}16.54 \\
16.76\end{array}$ & $\begin{array}{l}2.21 \\
1.53\end{array}$ & 0.09 & 0.76 \\
\hline Sit-ups in 60 s (freq) & $\begin{array}{l}1 \\
2\end{array}$ & $\begin{array}{l}27.38 \\
32.23\end{array}$ & $\begin{array}{c}11.67 \\
6.91\end{array}$ & 1.75 & 0.20 \\
\hline Flamingo (freq) & $\begin{array}{l}1 \\
2\end{array}$ & $\begin{array}{l}\mathbf{1 4 . 4 2} \\
18.91\end{array}$ & $\begin{array}{l}6.30 \\
6.01\end{array}$ & 3.05 & 0.09 \\
\hline
\end{tabular}

$$
F=10.61 \quad P=0.04
$$

\begin{tabular}{|c|c|}
\hline \multirow{3}{*}{$\begin{array}{l}\text { Gr - groups of examinees: } \\
\text { 1) rhythmic gymnasts } \\
\text { 2) modern dancers }\end{array}$} & f - f-test for univariate analysis of variance \\
\hline & $\mathrm{p}$ - level of statistical significance for $\mathrm{f}$ \\
\hline & F- F-test for multivariate analysis of variance \\
\hline $\mathrm{AM}$ - arithmetic mean & $\mathrm{P}$ - level of statistical significance for $\mathrm{F}$ \\
\hline SD - standard deviation & \\
\hline
\end{tabular}

The results obtained from the coordination assessment test in the backwards polygon test indicate that the motor skill is more significantly developed in the examinees practising rhythmic gymnastics compared to the those doing modern dance. With constant work done in each training session, this motor skill can be significantly improved and developed in both groups' athletes.

The results of the analysed differences in pliability test assessment in the examined sample show that there are statistically significant differences between the two groups of examinees with better results achieved by the girls doing rhythmic gymnastics. Particular attention should be paid to this motor skill in the training process since it is of particular importance for performing movements of larger amplitudes entailing all bodily segments 
of esthetic significance both in rhythmic gymnastics and modern dances. Specific requirements for particular difficulty elements within the competition rulebook according to which choreographies are prepared involve performing all movements, predominately jumps, expressive elements, pliability and movability elements, turns, etc. with large amplitude. Accordingly, a significant portion of time is devoted to developing this necessary motor skill in the training process, which in turn involves all bodily segments.

The results of the tests concerning lower-limb explosive strength assessment are significantly better in girls practising modern dancing compared to those doing rhythmic gymnastics at the level of statistical significance with the value $\mathrm{p}=0.05$. The activities requirements in the two groups of examinees are similar, as choreographies have been composed of a large number of jumps and skips. For satisfactory performance of the abovementioned and many other explosive elements, possibly the prevailing factor in the physical preparation of rhythmic gymnasts and dancers is the constant work on developing explosive strength of all bodily segments, and most of all, lower limbs.

The results of the tests assessing repetitive trunk strength, agility and balance indicate that, statistically, there is no big difference among them when comparing the two groups of examinees. The findings indicate an almost equal development of the given motor skills in both groups. Rhythmic gymnastics and modern dance requirements abound in the elements of body weight such as static movements, guided movements, frequently large amplitudes, movements performed with fast body movement in the area where it is required to develop all forms of strength in order to achieve their high-quality performance, as well as balance required for satisfactory performance of bodyweight balance elements.

Table 2. presents an analysis of differences in motors variables between the group of girls practising rhythmic gymnastics and the team doing modern dancing, aged 9-11. The results of the multivariate analysis of variance in this age indicate statistically significant differences of the entire system of motor variables between the examined groups at the level of statistical significance being $\mathrm{P}=0.00$.

Table 2. Analysis of differences of motor variables between two groups of girls aged 9-11

\begin{tabular}{|c|c|c|c|c|c|}
\hline VARIABLES & Gr & $\mathbf{A M}$ & SD & $\mathbf{f}$ & $\mathbf{p}$ \\
\hline Obstacle course backwards (s) & $\begin{array}{l}1 \\
2 \\
\end{array}$ & $\begin{array}{l}\mathbf{1 6 . 2 2} \\
18.07\end{array}$ & $\begin{array}{l}4.17 \\
5.69 \\
\end{array}$ & 2.27 & 0.14 \\
\hline Threading and skipping (s) & $\begin{array}{l}1 \\
2 \\
\end{array}$ & $\begin{array}{l}15.94 \\
15.16 \\
\end{array}$ & $\begin{array}{l}3.26 \\
3.03 \\
\end{array}$ & 1.11 & 0.30 \\
\hline Standing broad jump (cm) & $\begin{array}{l}1 \\
2 \\
\end{array}$ & $\begin{array}{c}145.97 \\
\mathbf{1 5 8 . 6 7} \\
\end{array}$ & $\begin{array}{l}16.47 \\
16.09 \\
\end{array}$ & 10.89 & 0.00 \\
\hline Triple jump (cm) & $\begin{array}{l}1 \\
2 \\
\end{array}$ & $\begin{array}{l}426.03 \\
\mathbf{4 3 2 . 8 3} \\
\end{array}$ & $\begin{array}{l}52.75 \\
55.44 \\
\end{array}$ & 2.39 & 0.15 \\
\hline Left leg front raise $\left(^{\circ}\right)$ & $\begin{array}{l}1 \\
2 \\
\end{array}$ & $\begin{array}{l}\mathbf{1 3 3 . 9 0} \\
111.63 \\
\end{array}$ & $\begin{array}{l}13.65 \\
15.40 \\
\end{array}$ & 40.51 & 0.00 \\
\hline Right leg front raise $\left(^{\circ}\right)$ & $\begin{array}{l}1 \\
2\end{array}$ & $\begin{array}{l}\mathbf{1 3 9 . 9 7} \\
116.33\end{array}$ & $\begin{array}{l}12.81 \\
16.38\end{array}$ & 43.54 & 0.00 \\
\hline Left leg lateral lift $\left({ }^{\circ}\right)$ & $\begin{array}{l}1 \\
2\end{array}$ & $\begin{array}{c}\mathbf{1 3 5 . 3 1} \\
85.65\end{array}$ & $\begin{array}{l}11.65 \\
10.12\end{array}$ & 380.78 & 0.00 \\
\hline Right leg lateral lift $\left(^{\circ}\right)$ & $\begin{array}{l}\mathbf{1} \\
2 \\
\end{array}$ & $\begin{array}{c}\mathbf{1 3 5 . 4 5} \\
86.87\end{array}$ & $\begin{array}{c}12.54 \\
8.26 \\
\end{array}$ & 409.78 & 0.00 \\
\hline Left leg rear raise $\left(^{\circ}\right)$ & $\begin{array}{l}1 \\
2 \\
\end{array}$ & $\begin{array}{l}\mathbf{8 7 . 9 7} \\
55.46 \\
\end{array}$ & $\begin{array}{l}11.95 \\
13.28 \\
\end{array}$ & 114.96 & 0.00 \\
\hline Right leg rear raise $\left(^{\circ}\right)$ & $\begin{array}{l}\mathbf{1} \\
2\end{array}$ & $\begin{array}{l}\mathbf{8 5 . 6 2} \\
55.41\end{array}$ & $\begin{array}{l}11.20 \\
12.53\end{array}$ & 112.05 & 0.00 \\
\hline $\begin{array}{l}\text { Deep forward bend while } \\
\text { seated straddled }(\mathrm{cm})\end{array}$ & $\begin{array}{l}\mathbf{1} \\
2 \\
\end{array}$ & $\begin{array}{l}63.00 \\
57.94\end{array}$ & $\begin{array}{l}7.43 \\
9.23 \\
\end{array}$ & 6.18 & 0.01 \\
\hline Side stepping (freq) & $\begin{array}{l}1 \\
2\end{array}$ & $\begin{array}{l}12.72 \\
\mathbf{1 5 . 8 3}\end{array}$ & $\begin{array}{l}0.92 \\
1.94\end{array}$ & 65.62 & 0.00 \\
\hline T-test (s) & $\begin{array}{l}1 \\
2\end{array}$ & $\begin{array}{l}\mathbf{1 4 . 0 9} \\
14.71\end{array}$ & $\begin{array}{l}4.87 \\
4.73\end{array}$ & 1.92 & 0.17 \\
\hline Sit-ups in 60s (freq) & $\begin{array}{l}1 \\
2\end{array}$ & $\begin{array}{l}37.21 \\
37.20\end{array}$ & $\begin{array}{l}7.23 \\
9.72\end{array}$ & 0.00 & 0.99 \\
\hline Flamingo (freq) & $\begin{array}{l}1 \\
2\end{array}$ & $\begin{array}{c}9.52 \\
16.23\end{array}$ & $\begin{array}{l}5.21 \\
7.06\end{array}$ & 19.15 & 0.00 \\
\hline
\end{tabular}

$\mathbf{F}=49.11 \quad P=0.00$ 
The results of the univariate analysis of variance (ANOVA) clearly indicate that there is a statistically significant difference between the examinees concerning most variables assessing motor skills at the high level of statistical significance being $\mathrm{p}=0.01$.

Having analysed the results of the arithmetic mean values of each motor variable, we identified better results in favour of the examinees practising rhythmic gymnastics, hereby indicating that in the motor skills assessment tests, rhythmic gymnasts presented better development level of the given skills.

Generally speaking, the majority of motor variables showed a difference at the high level of statistical inference even though it is not discernible when one aspect of statistical inference is considered in the younger group of examinees. The majority of motor variables showed a difference at the high level of statistical inference. The multivariate $\mathrm{F}$ distribution and $\mathrm{F}$ test (univariate analysis of variance) revealed a far more significant, and thus higher degree of difference between the examinees within the older age group as opposed to the younger one. This may only lead to a conclusion that the girls practising rhy thmic gymnastics and dancing for a longer period (longer dancing experience of the older age group compared to the younger age group- AS - 3.43 regarding 2.27 years of age) develop motor skills typical of the sport at a significant proportion, which was also found by some other researchers examining similar population $[7,23,24]$.

\section{Conclusions}

Having observed motor strengths of the both analysed age groups, we may conclude that the girls practising rhythmic gymnastics are statistically significantly different quantitatively speaking from the girls doing modern dancing, in most cases, at the high level of statistical inference. This difference is reflected in better coordination development, balance and, most of all, the flexibility of lower limbs in rhythmic gymnasts, i.e. explosive strength, and agility in modern dancers. Such a difference is particularly noticeable in the age group where the examinees have been doing both types of activities for a more extended period, on average, and thus significantly improved their skills due to being involved in rhythmic gymnastics.

Apart from the contribution to motor ability development, rhy thmic gymnastics and dance activity affect the psyche as they impact intellectual abilities, functional abilities, improve health and help to form various social values, enhance artistic creativeness. Finally, they may have an application in sports training, recreation and physical education lectures [25].

A recreational artistic and rhythmic gymnastics is associated with muscle hypertrophy and enhanced bone mineral density in prepubertal girls. Participation in rhythmic gymnastics could thus become a stimulus that elicits an osteogenic response in prepubertal girls [26].

The results of fourteen studies point to consistent effects across a range of different populations and settings that suggest that recreational dance can improve cardiovascular fitness and bone health in children and young people. It can also contribute to preventing or reducing obesity. Further, there is some limited evidence which suggests that dance participation may improve self-perception of one's body image and reduce anxiety. Other evidence suggests that involvement in dance may have some positive outcomes on one's physical and psychosocial well-being [27].

In spite of the increased recognition of the importance of dance in health care, it is still infrequently equated with exercise. Dance can be as beneficial as jogging along a track, biking, swimming, or running on the treadmill. The exercise benefits of dance include increased flexibility, increase in muscle strength and tone, better endurance, cardiovascular conditioning, balance and spatial awareness, and a general feeling of wellbeing [28]. Modern dance is characterised by much incessant movement, by hopping, lateral movement and swift, accurate moves, balance and flexibility elements, repetitive movements such as hip drips, figure eights, circles, and shimmies, which can put the lower back and hip joints and ligaments through a full range of motion that increases the muscle tone and improves posture, thereby aiding in the prevention of lower back problems. Dance also helps the older brain form new interconnections and to work faster as well as increases the temporal and prefrontal brain activity [28].

If we want an optimum development of children and a solid ground for further practising sports and recreational activities, as well as a lifestyle with well-developed anthropological abilities and skills (that are needed later for schooling, studies, workplace and everyday life), it is required to provide multi-layered and varied motor stimulants. In other words, it is extremely vital to provide children with a daily high-quality physical activity that has been well thought over. Accordingly, one of the quality activities at preschool and younger age is rhythmic gymnastics and modern dance, especially for the female population. 


\section{References:}

1. Claessens A, Lefevre J, BeunenG, Malina RM. The contribution of anthropometric characteristics to performance scores in elite female gymnasts. Journal of Sports Medicine and Physical Fitness; 1999, 39(4): 355-360.

2. Evans S, Davy K, Stevenson E, Seals D. Physiological determinants of 10 -km performance in highly trained female runners of different ages. Journal of Applied Physiology. 1995; 78(5): 1931-1941.

3. Russel K. Gymnastic talent from detection to perfection. In: Petiot B, Salmela JH, Canada: Sport Psyche Editions; Hoshizaki TB, editors. World Identification Systems for Gymnastic Talent. Montréal; 1987. p. 4-13.

4. Elferink-Gemser M, Visscher C, Lemmink K, Mulder T. Relation between multidimensional performance characteristics and level of performance in talented youth field hockey players. Journal of Sports Sciences. 2004; 22(11-12): 1053-1063.

5. Blanksby B, Bloomfield J, Ponchard M, Ackland T. The relationship between anatomical characteristics and swimming performance in state age-group championship competitors. Journal of Swimming Research. 1986; 2(2): 30-36.

6. Douda H, Toubekis A, Avloniti A, Tokmakidis S. Physiological and Anthropometric Determinants of Rhythmic Gymnastics Performance. International Journal of Sports Physiology and Performance. 2008; 3: 41-54.

7. Alricsson M, Harms-Ringdahl K, Eriksson K, Werner S. The effect of dance training on joint mobility, muscle flexibility, speed and agility in young cross-country skiers; a prospective controlled intervention study. Scandinavian Journal of Medicine \& Science in Sports. 2003; 13(4): 237-243.

8. Angioi M, Metsios S, Twitchett E, Koutedakis Y, Wyon M. Association Between Selected Physical Fitness Parameters and Aesthetic Competence in Contemporary Dancers. Journal of Dance Medicine \& Science. 2009; 13(4): 115-123(9).

9. Martos E. Performance measurement of female gymnasts. Hung Rev Sport Med. 1991; 32(2): 99-106.

10. Hume PA, Hopkins WG, Robinson DM, Robinson SM, Hollings SC. Predictors of attainment in rhythmic sportive gymnastics. J Sports Med Phys Fitness. 1993; 33(4): 367- 377.

11. Douda H, Tokmakidis S, Tsigilis N. Effects of specific training on muscle strength and flexibility of rhythmic sports and artistic female gymnasts. Coach Sport Sci J. 2002; 4(1): 23-27.

12. Jovanović $S$, Tešanović G, Bošnjak G. Speed, agility and explosive strength as components of jazz ballet dancers' training process. Proceedings of the 5th International Congress Youth sport 2010. Ljubljana. p. 229233.

13. Clarkson P, Freedson P, Keller B, Carney D, Skrinar M. Maximal oxygen uptake, nutritional patterns, and body composition of adolescent female ballet dancers. Research Quarterly for Exercise and Sport. 2013; 56(2): 180-185.

14. Cohen J, Segal K, Witriol I, McArdle W. Cardiorespiratory responses to ballet exercise and the VO2max of elite ballet dancers. Medicine \& Science in Sports \& Exercise. 1982; 14(3): 212-217.

15. Koutedakis Y, Sharp N. The fit and healthy dancer. Chichester: John Wiley and Sons; 1999.

16. Clarkson P. The science of dance. In: Clarkson P, Skrinar M. editors. The science of dance training. Champaign (IL): Human Kinetics Books; 1988. p. 17-21.

17. Fitt S. Conditioning for dancers: investigating some assumptions. Dance Research Journal. 1982; 14(1): 32-38.

18. Van Gyn G. Contemporary stretching techniques: Theory and application. In: The Dancer as Athlete: The 1984 Olympic Scientific Congress Proceedings. Champaign, Illinois: Human Kinetics Publishers, Inc.; 1986. p. 109-116.

19. Hergenroeder A, Brown B, Klish W. Anthropometric measurements and estimating body composition in ballet dancers. Medicine and Science in Sports and Exercise. 1993; 25(1): 145-150.

20. Claessens A, Beunen G, Nuyts M, Lefevre J, Wellens R. Body structure, somatotype, maturation and motor performance of girls in ballet schooling. The Journal of Sports Medicine and Physical Fitness. 1987; 27(3): 310-317.

21. Koutedakis Y, Jamurtas A. The Dancer as a Performing Athlete. Sports Med. 2004; 34(10): 651-661.

22. Bala G, Stojanović M, Stojanović M. Merenje i definisanje motoričkih sposobnosti dece. Novi Sad: Fakultet sporta i fizičkog vaspitanja; 2007.

23. Viskić-Štalec N, Štalec J, Katić R, Podvorac Đ, Katović D. The Impact of Dance-Aerobics Training on the Morpho-Motor Status in Female High-Schoolers (Uticaj plesno-aerobnog treninga na morfo-motorički status gimnazijalki). Collegium Antropologicum. 2007; 31(1): 259-266.

24. Uzunović S. The transformation of strength, speed and coordination under the influence of sport dancing (Transformacija snage, brzine i koordinacije pod uticajem modernog sportskog plesa). Facta Universitas. 2008; 6: 135-146. 
25. Ladešić S, Mrgan J. Ples u realizaciji antropoloških zadaća tjelesne i zdravstvene kulture. [Dance in the implementation of the anthropological task of physical education.] Paper presented at 16. ljetna škola kineziologa Hrvatske, Poreč, Croatia, June 19-23, 2007.

26. Vicente-Rodriguez G, Dorado C, Ara I, Perez-Gomez J, Olmedillas H, Delgado-Guerra, et al. Artistic versus rhythmic gymnastics: effects on bone and muscle mass in young girls. International Journal of Sports Medicine. 2007; 28(05): 386-393.

27. Burkhardt J, Brennan C. The effects of recreational dance interventions on the health and well-being of children and young people: A systematic review. Arts \& Health. 2012; 4(2): 148-161.

28. Alpert PT. The health benefits of dance. Home Health Care Management \& Practice. 2011; 23(2): $155-157$. 